MATEC Web of Conferences 37, 01034 (2015)

DOI: $10.1051 /$ matecconf $/ 20153701034$

(C) Owned by the authors, published by EDP Sciences, 2015

\title{
ENERGY-SAVING VIBRATION IMPULSE COAL DEGRADATION AT FINELY DISPERSED COAL-WATER SLURRY PREPARATION
}

\author{
V.A. Moiseev ${ }^{1}$, V.G. Andrienko ${ }^{1}$, V.G. Pileckij ${ }^{1}$, L.P. Zarogatskij, \\ Yu.S. Borovikov ${ }^{2}$, V.E. Gubin ${ }^{2}$, A.S. Matveev", a \\ ${ }^{1}$ Closed joint stock company 'KOMPOMASh-TJeK', Moscow \\ ${ }^{2}$ Tomsk Polytechnic University, Tomsk
}

\begin{abstract}
Theoretical and experimental research results of processes of finely dispersed coal-water slurry preparation for further generation of energetic gas in direct flow and vortex gas generator plants have been presented. It has been stated that frequency parameters of parabolic vibration impulse mill influence degradation degree. Pressure influence on coal parameters in grinding cavity has been proven. Experimental researches have proven efficiency of vibration impulse mill with unbalanced mass vibrator generator development. Conditions of development on intergranular walls of coal cracks have been defined.
\end{abstract}

\section{Introduction}

Operational experience of direct flow and vortex gas generator plants [1-6] allows making a conclusion that finely dispersed coal-water slurry processes (FDCWS), gasification process and receivable raw material refining make main costs (up to $70 \ldots 80 \%$ ) at energetic gas production. It is known [5-8] that geometric parameters of coal particles in FDCWS composition should not exceed 10·10-6 m [9-11]. Preparation of required parameters of FDCWS demands creation of special grinding equipment [7-9]. Theoretical and experimental researches done before [10-12] allow highlighting one of priority variants of FDCWS production - parabolic vibration impulse inertial mill development. Compared to installations with two freedom degrees, parabolic vibration impulse mill is a system with up to 10 freedom degrees [13-14]. The main advantage of eccentric cone grinders in comparison with traditional grinding apparatuses are [1-4]: decrease of required space; operational simplicity; electrical energy consumption decrease; diffusivity coefficient up to $90 \%$; grinding degree 4...6. It is known [3-7] that for the last 20...30 years famous engineering companies (such as Metso Oyj, Telsmith, Sandvik Coroman, Kobelco Construction Machinery) created universal cone eccentric mills of high productivity and safety. Moreover grinding degree was the same and operational costs managed to reduce for not more than $7-8 \%$. Radical process possibilities of fining proved to be almost exhausted.

\footnotetext{
a Corresponding author: dim2003@tpu.ru
} 
It should be noted that the most universal mill of all existing ones, and able to degrade materials with durability up to 20 on M.M. Protod'jakonov's scale, is cone eccentric grinder made for small grinding in $20^{\text {th }}$ last century and have not been principally changed since then [15-17].

The purpose of this work is theoretical and experimental research processes of FDCWS preparation (with further energetic gas receiving) with energy saving equipment use - parabolic vibration impulse mill.

The following researches were done for technological and constructive solutions at high efficiency equipment for grinding creation:

- dynamics of parabolic vibration impulse mills influence;

- vibration impulse grinding forces with optimization ratio of their components;

- ways of technological process of vibration impulse influence on product able to be ground indexes control.

\section{Theoretical and experimental researches}

Vibration impulse mill consists of a body set on a vibration basement and connected with it by means of a spherical bearing, asymmetric parabolic cone and two unbalance vibrators one of which rotates around the axis of parabolic cone and the other - around the axis of the body.

Model mill was developed for research of dynamics of parabolic vibration impulse mill influence for FDCWS preparation. Model mill has two unbalance vibrators one of which is a drive of parabolic cone and the other made in body bearing balances inertial forces of drive unbalance and parabolic cones. Maximum static moment of unbalance on the body $\mathrm{Sd}(\mathrm{a})=0.58 \mathrm{kgm}$ is defined by design.

It should be noted that static moment of unbalance on the body changed within 0 to $0.58 \mathrm{kgm}$ at research of dynamics of influence on coal and water.

The researches were done for seven points on the working surface of basin armor within the given cross sections of grinding chamber (fig. 1) from 0 to $0.58 \mathrm{kgm}$. The thickness of material layer in unloading area of grinding chamber was taken as $1 \mathrm{~mm}$.

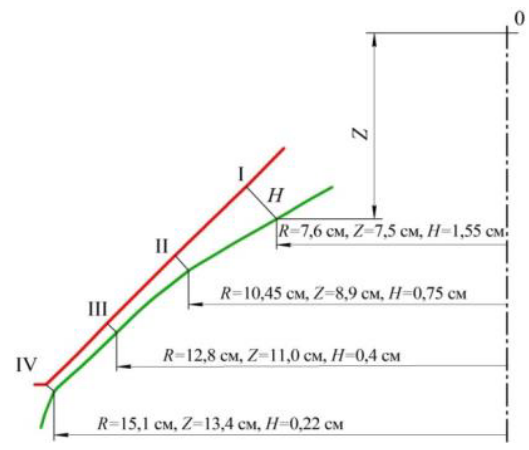

Figure 1. Geometric parameters of grinding chamber of model mill

Theoretical researches showed that for stable spinning of internal parabolic cone along the outer one it is necessary to set ring unloading gap between them with setting less than the defined one, which is called critical gap Skp (it is gap setting at which power given to the cone of unbalance from electrical drive can still compensate expenses on grinding process) and at which the above-mentioned spinning, and effective grinding, consequently, are not possible. Formula of critical gap definition is as follows [18]:

$$
\text { Sкр }=\mathrm{k}\left(\mathrm{S} \_\mathrm{c} 1\right) / \mathrm{I} \_\mathrm{b} \mathrm{d},
$$

where 1 - interval from the center of rolling movement of parabolic cone to the plane of rolling unbalance center of gravity; Ib - inertia moment of parabolic cone in relation to the axis coming through the center of its rolling movement and perpendicular to its axis: $d$ - interval between the 
center of rolling movement of parabolic cone to the edge of its armor, at the exit of grinding cavity: Sc - static moment of unbalance: $\mathrm{k}=3$ - spinning stability coefficient.

The research of control ways of technological parameters of vibration processes influencing grindable product showed as follows:

- $\quad$ static moment and frequency of vibrator spinning influence on technological parameters;

- $\quad$ size of unloading gap and grinding chamber profile;

- methods of setting on selective grinding;

- $\quad$ dry and wet grinding and its technological advantages.

The research of static moment influence and frequency of vibrator spinning on technological parameters were done on the model of parabolic vibration impulse mill. The research was done in conditions of stepwise change of one of the above-stated factors for objective assessment of the influence on the process of grinding differently for each of them, without changing another factor. Pressure was taken hypothetically equal to 2, 3 and $4 \mathrm{MPa}$. Frequency of unbalance spinning (rolling movement of internal parabolic cone) was fixed as 1280, 1480 and 1780 min-1 [5-9]. Unloading gap was maintained constant (equal to $0.5 \mathrm{~mm}$ ) at all modes. Source raw material - coal of standard D with water.

It was stated that size of average weighted piece of coal in slurry degreases by 2 times on the average with the increase of rolling movement of internal parabolic cone which is clear from the curves in picture $2 \mathrm{a}$. Increase of rolling movement of internal parabolic cone enables increase of grinding degree with a small of decrease production. This way is the most effective at small centrifugal forces of unbalance. It is clear from pic. $6 \mathrm{~b}$ that pressure increase in grinding cavity by 2 times at constant frequency leads to productivity increase on all frequencies on the average by $18 \%$, and it also leads to linearly proportional decrease of average weighted piece of coal in slurry (pic. 82).

a)

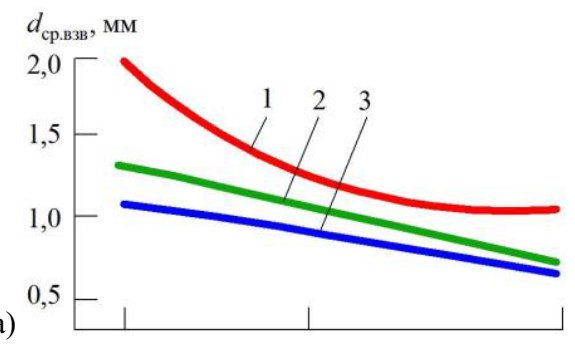

б)

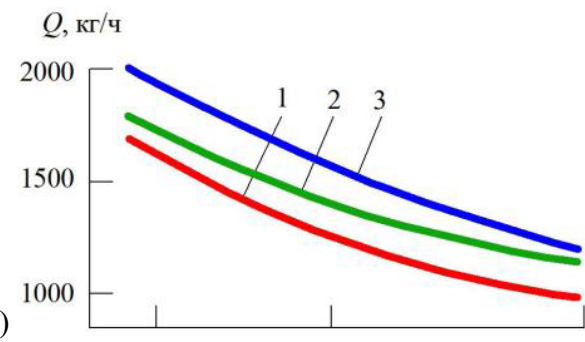

Figure 2. Dependence of productivity Q(a), average weighted piece dep.wtd. (b) and fraction composition 0.25 $\mathrm{mm}$

The researches showed that increase of pressure on slurry which is in grinding cavity enables increase of productivity and degree of grinding by means of deformation degree increase of coal layer processed with water. Changing frequency of rolling movement of internal parabolic cone and static moment of unbalance at unchanged profile of grinding cavity, in open cycle conditions, it is possible to receive any granulometric composition of slurry within the limits of curves shown in pic. 5 .

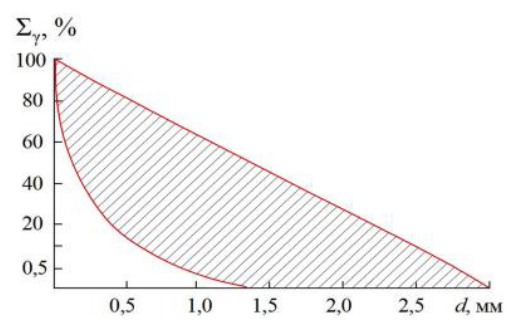

Figure 3. Limits of granulometric composition of grindable coal in slurry regulation 
The research on mill model showed that nominal coarseness of its product (for coal of average coarseness) equal to $0.2 \mathrm{~mm}$ can be decreased by 1.5 times, i.e. to $0.13 \mathrm{~mm}$, thus providing condition for finely dispersed coal grinding in slurry mainly by means of pressure increase in grinding cavity.

In particular, it was stated that at constant frequency of rolling movement of internal parabolic cone average weighted coarseness of coal in slurry decreases in direct proportion to pressure increase in grinding cavity from centrifugal force of unbalance. In the same conditions when frequency increases by $12 \%$ with simultaneous increase of pressure in grinding cavity by $23 \%$, average weighted coarseness of coal in slurry decreases by $25 \%$.

\section{Conclusion}

Theoretical and experimental researches allow making some conclusions. First, frequency increase of rolling movement of internal parabolic mill cone allows reducing coal fraction in slurry two times on the average. Second, frequency increase influences output with higher concentration of fraction to a less extent $25 \cdot 10-4 \mathrm{~m}$. Thus, frequency increase of rolling movement of internal parabolic cone enables increase of grinding degree at a small decrease of mill productivity. It has been stated that pressure increase on slurry being in grinding cavity enables productivity and grinding degree increase. The researches on mill model have shown:

- nominal coal coarseness in slurry makes $2 \cdot 10-4 \mathrm{~m}$ and can be decreased by about 1.5 times (to $13 \cdot 10-4 \mathrm{~m}$ ) by means of pressure increase in grinding cavity;

- depending on mill feeding coarseness grinding degree can change from 5 to 18 at almost constant average productivity.

Use of parabolic vibration impulse mill for grinding pieces of coal with water up to $6 \cdot 10-2 \mathrm{~m}$ showed that slurry with nominal coarseness less than 200.10-6 m can be received without engine power consumption increase. Developed parabolic vibration impulse mill means that grinding force is not defined by coarseness of grindable material and degree of filling grinding chamber as in typical eccentric grinders but by centrifugal forces of unbalance and grinding parabolic cone. Water feeding into grinding cavity of parabolic vibration impulse mill with closed cycle organization will provide equal productivity with electrical energy consumption 2-3 times less than with traditional equipment. The important condition coming from the theory of selective opening is creation of volumetric stress on intergranular walls with definite measured level which is enough for development of cracks in them.

The work has been done in framework of federal focused program implementation "Research and Development on Priority Orientation of Science and Technology Complex Development in Russia 2014-2020", unique identifier 'Applied Research and Experimental Developments' RFMEFI58114X0001.

\section{References}

1. V.L. Egorov, Magnitnye, jelektricheskie i special'nye metody obogashhenija rud, (1977).

2. N.M. Karnauhov, Tehnologija dovodki kollektivnyh koncentratov s pomoshh'ju jelektricheskoj separacii, (1966).

3. I.A. Kakovskij, V.I. Revnivcev, O vlijanii sostojanija poverhnosti na process jelektricheskoj separacii mineralov s maloj jelektroprovodnost'ju. V Mezhdunarodnyj kongress po obogashheniju poleznyh iskopaemyh, (1962).

4. N.F. Olofinskij, V.A. Novikov, Triboadgezionnaja separacija, (1974).

5. Fraus F., Electrostatic separation of granular materials. U.S. Dept. of the interior Bureau of Mines, (1962).

6. A.I. Mamedov, Fizicheskie metody obogashhenija kamennyh rud, (1979).

7. A.I. Mesenjashin, Jelektricheskaja separacija v sil'nyh poljah, (1978). 
8. I.P. Vereshhagin, G.Z. Levitov, Osnovy jelektrogazodinamiki dispersnyh sistem, (1974).

9. A.I. Angelov, B.C. Ershov, S.I. Losaberidze, M.M. Pashni, Dvizhenie zarjazhennyh chastic v jelektrostaticheskom pole koronno-jelektrostaticheskogo barabannogo separatora. Jelektronnaja obrabotka materialov, (1978).

10. A.D. Zimon, Adgezija pyli poroshkov, (1979).

11. Je.V. Volkova, G.V. Zhus', D.V. Kuz'min, Dijelektricheskaja separacija razlichnyh polikoncentratov i materialov, (1975).

12. I.N. Plaksin, N.F. Olifinskij, Koronnaja jelektroseparacija i primenenie ee dlja obogashhenija, klassifikacii i obespylivanija, Jenergeticheskie i magnitnye metody separacii, (1965).

13. A.P. Kovalev, Jelektricheskoe obogashhenija ugol'noj pyli, (1950).

14. V.I. Levitov, Korona peremennogo toka. Voprosy teorii metodov issledovanija i teoreticheskih harakteristik, Avtoreferat na soiskanie uchenoj stepeni doktorara tehn. nauk, (1966).

15. N.F. Olefinskij, Jelektroseparacija gorelyh zemel' litejnyh cehov, Vestnik mashinostroenija, (1947).

16. A.V. Degtjarenko, I.F. Kashkarov, Rol' i vozmozhnosti jelektricheskoj separacii v tehnologii obogashhenija kompleksnyh titanovyh rud, Sovershenstvovanie processov jelektroseparacii i koncentracii jelektroseparatorov, (1987).

17. M.V. Bachkovskij, Jelektricheskaja provodimost' materialov i opredelenie udel'nogo soprotivlenija, Teorija i praktika jelektricheskih i magnitnyh metodov separacii poleznyh iskopaemyh, (1968).

18. A.I. Urvancev, Razrabotka vysokoproizvoditel'nogo barabannogo koronno-jelektrostaticheskogo separatora vertikal'nogo tipa, Cvetnye metally, (1995). 